\title{
Benthic nutrient fluxes along an estuarine gradient: influence of the pinnid bivalve Atrina zelandica in summer
}

\author{
M. Gibbs ${ }^{1, *}$, G. Funnell ${ }^{1}$, S. Pickmere ${ }^{1}$, A. Norkko ${ }^{2}$, J. Hewitt ${ }^{1}$ \\ ${ }^{1}$ National Institute of Water and Atmospheric Research Ltd., PO Box 11-115, Hamilton, New Zealand \\ ${ }^{2}$ Department of Marine Ecology, Göteborg University, Kristineberg Marine Research Station, 45034 Fiskebäckskil, Sweden
}

\begin{abstract}
Benthic nutrient fluxes (BNF) can supply 30 to $100 \%$ of the nutrient requirements of benthic and pelagic algae in an estuary, and can, thus, potentially sustain benthic and pelagic primary production within the estuarine food web. While BNF can be influenced by microbial processes, epibenthic suspension-feeding bivalves have the potential to alter fluxes by their influence on the community composition of surrounding macrofauna and benthic boundary conditions, and their feeding activities. In Mahurangi Harbour, New Zealand, the large suspension feeding pinnid Atrina zelandica (hereafter referred to as Atrina) occupies large areas of the harbour floor. Consequently, Atrina have the potential to substantially influence the BNF and, thus, primary production, and the food supply to the filter feeding community within the harbour, including the rack-farmed Pacific oyster aquaculture industry. Mahurangi Harbour is almost always isohaline, but exhibits a strong gradient in suspended sediment concentration, which declines from head to mouth. As Atrina increase their rate of pseudofaeces production with increases in suspended sediment concentration, we conducted in situ light and dark paired benthic chamber experiments with and without Atrina at 4 stations along this turbidity gradient, to determine their effect on BNF. Our results showed substantially greater BNF from Atrina beds than bare sediments. We also found greater net BNF (difference between Atrina beds and bare sediment) in the less turbid water under dark conditions, but enhanced water column nutrient supply in the more turbid water in light, due to Atrina excretion of ammoniacal nitrogen $\left(\mathrm{NH}_{4}-\mathrm{N}\right)$. On an areal basis, we estimate that BNF from Atrina beds may account for up to $80 \%$ of the nutrient supply for pelagic primary production and, thus, they are of major importance to the sustainability of aquaculture in this harbour.
\end{abstract}

KEY WORDS: Benthic nutrient flux $\cdot$ Benthic chambers $\cdot$ Estuarine turbidity gradient $\cdot$ Atrina zelandica $\cdot$ Microphytobenthos

\section{INTRODUCTION}

Benthic nutrient fluxes (BNF) can supply a substantial proportion of the nutrient requirements of benthic and pelagic algae in an estuary ( 30 to $100 \%$ ) and, thus, they potentially sustain the benthic and pelagic primary production within the estuarine food web (Kemp \& Boynton 1992, Berelson et al. 1998, Gibbs et al. 2002, Sundbäck et al. 2003). Generally, investigations of BNF concentrate on the role of microbial processes, associ- ated with coupled nitrification-denitrification, and the microphytobenthos, which intercept the nutrient fluxes at the sediment-water interface (e.g. Sundbäck et al. 2000, 2004). Microphytobenthos may fully utilise nutrients for growth in daylight (MacIntyre et al. 1996, Webster et al. 2002, Sundbäck et al. 2004), fix nitrogen (Newell et al. 2002), and increase the cohesiveness of the sediments, thereby reducing resuspension (Delgado et al. 1991, Stal 1994, Miller et al. 1996). However, the presence of benthic animals can also be an 
important part of the nutrient dynamics of an estuary (e.g. Newell et al. 2002).

Bioturbation and grazing pressure by macrofauna can destabilise the sediments (de Deckere et al. 2001), stimulating microbial activity and enhancing denitrification (Gilbert et al. 1998). However, the presence of large benthic animals may also stabilise the sediments, and affect the composition and functioning of macrofaunal communities (Cummings et al. 1998, 2001, Ellis et al. 2000, Norkko et al. 2001, Hewitt et al. 2002, Reise 2002). Abundant suspension-feeders may build loose hummocks, multi-species epibenthic thickets or solid reefs, accommodating diverse epibenthic assemblages. Their raised and rough surfaces alter benthic boundary conditions (Green et al. 1998) and, hence, turbulence (Reise 2002), while their biodeposits may enrich the sediments and smother the microphytobenthos. Below the sediment surface, tubes and burrows of sessile or discretely motile animals provide microoxic zones (Munksby et al. 2002) where biogeochemical transformations may impact on the BNF (Boynton et al. 1982, Dame \& Libes 1993, Gilbert et al. 1997, 1998, Herman et al. 2000, Sundbäck $\&$ Miles 2000).

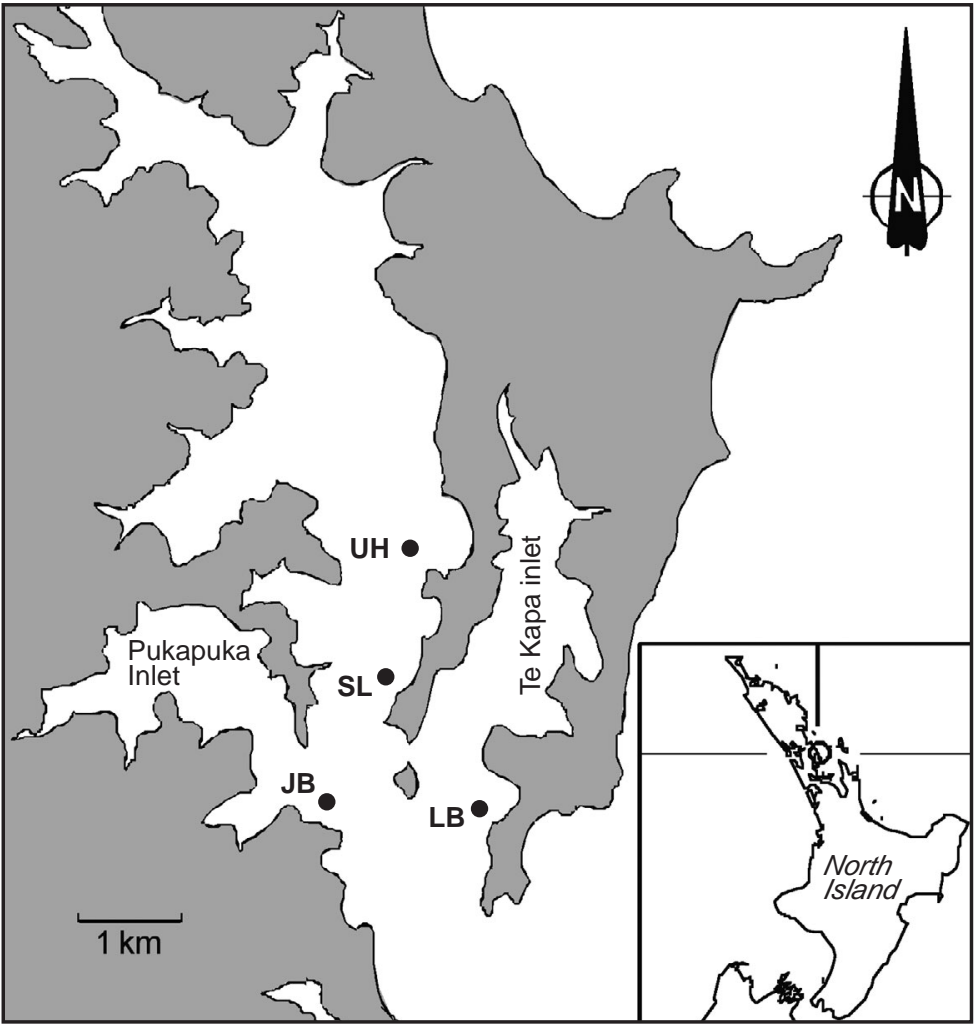

Fig. 1. Map of Mahurangi Harbour showing the location of the 4 study sites. Sites are approximately $1.5 \mathrm{~km}$ apart and have a 4 to $8 \mathrm{~m}$ water depth

In estuaries, strong gradients of salinity, turbidity, nutrients, and light can all influence primary production (Malone et al. 1988, Gallegos et al. 1992, Gibbs \& Vant 1997). Suspended sediment may be particularly important, influencing turbidity and light, and the feeding efficiency and biodeposit production of suspension feeders (Barillé et al. 1997, Hawkins et al. 1999). Suspended sediment loads may also determine the distributional limits of benthic macrofaunal suspension-feeders within the estuary (Quijón et al. 1996, Ellis et al. 2002). At Mahurangi, a small, $25 \mathrm{~km}^{2}$ harbour on the eastern shores of the North Island of New Zealand, populations of the largest benthic organism, the horse mussel Atrina zelandica Gray (hereafter referred to as Atrina) appear to be declining (authors' unpubl. data). Atrina are large (up to $30 \mathrm{~cm}$ long) suspension-feeding pinnid bivalves common in sandy and muddy soft-sediment subtidal environs around NE New Zealand (Powell 1979, Cummings et al. 1998). Atrina protrude above the sediment surface (commonly $7 \mathrm{~cm}$ ) and often form large patches of up to $100 \mathrm{~m}^{-2}$ (Hewitt et al. 2002) on the seafloor, adding to the complexity of the soft-sediment habitat by providing predation refuges and substrate for epifaunal attachment. Atrina have been found to increase their rate of biodeposit (pseudofaeces) production as sus-

pended sediment concentrations increase (Norkko et al. 2001, Ellis et al. 2002), which in turn may cause enhanced burial of microphytobenthos and changes in the BNF. Consequently, the decline in Atrina populations may have a major impact on the nutrient dynamics and productivity of this harbour.

We test this hypothesis by examining the spatial differences in benthic biomass, and nutrient and dissolved oxygen fluxes across the sediment-water interface in situ, with and without Atrina, along the turbidity gradient in Mahurangi Harbour. We also use natural abundance stable isotope signatures to establish links between the Atrina and the sediments in which they live.

\section{MATERIALS AND METHODS}

Study site. Mahurangi Harbour is a small $\left(25 \mathrm{~km}^{2}\right)$, shallow but deeply incised estuary in NE New Zealand (Fig. 1), extensively used for the rack culture of Pacific oysters Crassostrea gigas in the intertidal zone. As the main freshwater input is a relatively small stream (mean annual flow ca. $0.25 \mathrm{~m}^{3} \mathrm{~s}^{-1}$ ), the harbour is almost always isohaline (salinity $>33$ ). However, there 
is a strong turbidity gradient down the estuary. Four sites ca. $1.5 \mathrm{~km}$ apart were selected along the turbidity gradient on the main axis of Mahurangi Harbour (Fig. 1): Site UH, near the inner harbour limit of natural Atrina beds; Site LB, near the mouth of the harbour; and Sites SL and JB distributed between these other 2 sites. The sediments at these sites have previously been characterised (Ellis et al. 2002) as fine sandy silt at UH $(56.39 \mu \mathrm{m})$ and LB $(61 \mu \mathrm{m})$, and fine to medium sandy silt at SL and JB (105.50 $\mu \mathrm{m})$. Water depth at Sites $\mathrm{UH}, \mathrm{JB}$, and LB was around 4 to $5 \mathrm{~m}$ but around 8 to $9 \mathrm{~m}$ at SL, where there appeared to be bed scouring. Water flow within Mahurangi Harbour is driven mainly by the semi-diurnal tides, with maximum velocities of 0.3 and $0.7 \mathrm{~m} \mathrm{~s}^{-1}$ at peak neap and spring tides, respectively.

Three sites (SL, JB, and LB) were studied on 24 January 2001 (summer, Southern Hemisphere), and a more detailed study at all 4 sites was made on 6 February 2002. Both studies were conducted under bright sunny conditions, after an extended period without rain (Fig. 2A).

Atrina respiration and excretion. In January 2001, to quantify respiration and excretion rates, several Atrina of similar size (205 to $230 \mathrm{~mm}$ length) were collected from each of 3 sites (Sites SL, JB, and LB). Their shells were cleaned of epibenthos and they were conditioned in mesh bags at the same site overnight. On the following morning, the Atrina were retrieved and transported to the shore base in a troughs of aerated ambient seawater pending estimation of respiration and excretion rates. Individual Atrina were incubated in a 2.61 water-filled, opaque, stirred chamber, which was then sealed and submerged in a controlled temperature water-bath for $1 \mathrm{~h}$. Initial and final water samples were taken for analysis of dissolved oxygen (DO) and ammoniacal nitrogen $\left(\mathrm{NH}_{4}-\mathrm{N}\right)$. Atrina were initially incubated in water collected from the same site from which they were collected. Later, the Atrina from each site were incubated in high turbidity water from the inner harbour (Site UH). Three replicate measurements were made of each treatment. Controls were run concurrently without an Atrina in the chamber.

In situ incubations. Incubations were made in sets of 4 treatments, $<4 \mathrm{~m}$ apart, at each site: light and dark with 1 Atrina (treated), and light and dark without Atrina (controls), using stirred benthic chambers (area $0.25 \mathrm{~m}^{2}$; volume $0.025 \mathrm{~m}^{3}$ ). The $0.5 \mathrm{~m}$ square aluminium chamber bases were pressed into the sediments to a depth of $0.15 \mathrm{~m}$ by divers the day before incubation to seal any infaunal burrows and allow flushing of any sediment disturbance. Incubations began when divers installed the clear or blackened chamber lids and attached the stirrers. Ambient water samples were incubated with each set of chambers in

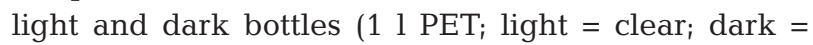
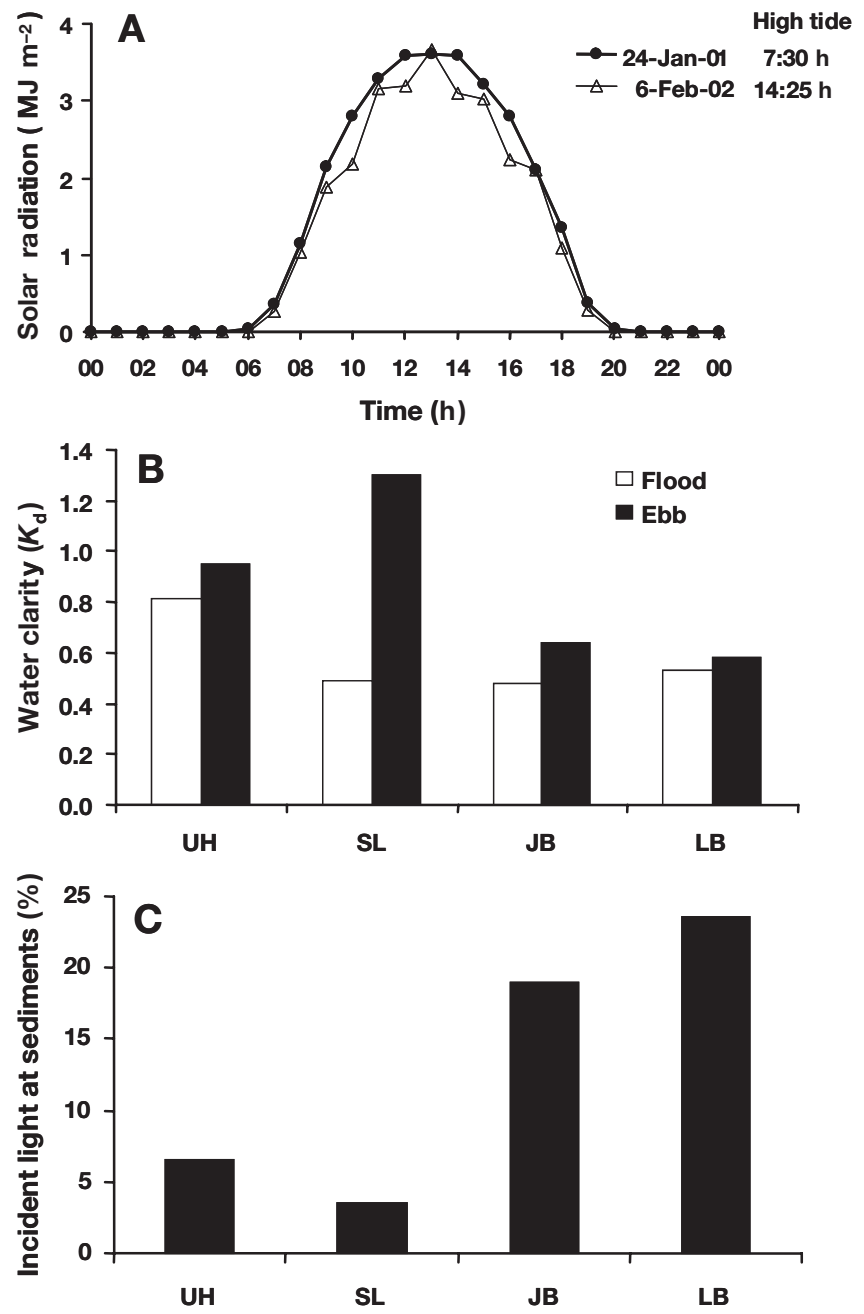

Fig. 2. (A) Solar radiation measured at Warkworth meteorological station at the head of Mahurangi estuary on the 2 sampling dates (NZST). (B) Water clarity $\left(K_{\mathrm{d}}\right)$ on the flood and ebb tide at each site. (C) Mean percentage of surface irradiance measured at the chamber depth at each site

wrapped in black tape) without sediment to allow correction for any water column effects. A replicate sample of ambient water was retained for immediate analysis of DO and subsequent nutrient analysis as the initial water sample.

Water samples were drawn from each benthic chamber, at timed intervals over a period of about $5 \mathrm{~h}$, via a $3 \mathrm{~mm}$ (inside diameter), hard, flexible, nylon tube to the surface, directly into a sample bottle, under reduced pressure. The initial volume of the tube $\left(7 \mathrm{ml} \mathrm{m}^{-1}\right)$ was discarded before the chamber water was collected. Replacement water into the chamber was supplied from a compensation water bag attached to the chamber via a connecting tube. The compensation water was also sampled and analysed to allow correction for chamber water nutrient dilution during sampling. 
Measurements. Profiles of photosynthetically active radiation (PAR) for downward irradiance were obtained using a Li-Cor model 194B cosine-corrected underwater sensor. Direct measurements of the percentage of surface light at the depth of the chambers were made in February 2002, and the attenuation coefficient $\left(K_{\mathrm{d}}\right)$ calculated at each site on the flood and ebb tide.

DO concentration was measured in each water sample, including initial samples, immediately upon collection, using a Yellow Springs Instrument (YSI) model 5731 stirred BOD bottle probe. Atrina and benthic respiration were measured as oxygen consumption in the dark chambers, and benthic gross primary production (GPP) was calculated from the net increase in oxygen in the light relative to dark chambers (e.g. Welsh et al. 2000). Values for respiration and GPP were corrected for water-column-only effects measured in the light and dark bottles incubated with the chambers at each site. GPP as $g$ carbon (C) $\mathrm{m}^{-2} \mathrm{~d}^{-1}$ was estimated using the oxygen-to-carbon conversion factor of $0.31 \mathrm{~g} \mathrm{C} \mathrm{g}^{-1} \mathrm{O}_{2}$ (Schramm et al. 1984).

The water samples were filtered under reduced pressure $(<20 \%$ reduction to avoid cell rupture) through Whatman $2.5 \mathrm{~cm} \mathrm{GF/C} \mathrm{glass} \mathrm{fibre} \mathrm{filters} \mathrm{directly} \mathrm{into}$ the sample storage bottle on a portable collecting vacuum manifold. The initial $20 \mathrm{ml}$ of sample was used to rinse the filter and sample bottle, and was discarded. All filtrations were performed onboard the boat on site and completed within $1 \mathrm{~h}$ of collection. All water samples were stored on ice pending freezing and returning to the laboratory for analysis. Particular care was taken to ensure that handling procedures did not introduce $\mathrm{NH}_{4}-\mathrm{N}$ contamination.

Water and sediment samples for algal species dominance were preserved in Lugol's iodine solution prior to settling in Utermöhl chambers and investigation using an inverted Lietz microscope (Utermöhl 1958).

Where appropriate, filters were retained for chlorophyll a determination. Each filter was folded in half (inwards) and stored in an individual polycarbonate envelope (Secol security envelopes, Secol) in a watertight, sealed plastic bag on crushed ice in the dark pending freezing and analysis on return to the laboratory. Chlorophyll filters were analysed by the $90 \%$ acetone extraction method of Strickland \& Parsons (1972).

Sediment cores (two $2.5 \mathrm{~cm}$ diameter, $2 \mathrm{~cm}$ deep) from each chamber for chlorophyll determination were extracted from freeze-dried aliquots by boiling in $95 \%$ ethanol. The absorbance of the extract at 665 and $750 \mathrm{~nm}$, before and after acidification with hydrochloric acid, was measured in a Shimadzu UV160A spectrophotometer. Sediment chlorophyll concentration was calculated using the equations of Sartory (1982).
Sediment organic content was determined gravimetrically on a ca. $6 \mathrm{~g}$ (wet wt) aliquot which was oven- dried at $98^{\circ} \mathrm{C}$ for $48 \mathrm{~h}$, weighed, combusted at $550^{\circ} \mathrm{C}$ for $3 \mathrm{~h}$, and reweighed. Organic content was calculated as the loss on combustion.

One Atrina specimen from each site in 2002 was measured and dissected to separate stomach, gonad, and flesh before stable isotope analysis without lipid extraction. All tissue samples were freeze-dried and stored in sealed containers pending analysis.

Freeze-dried sediment and Atrina tissue samples for stable isotope determination were weighed into pure tin (Sn) capsules, combusted in a Fisons NR1500 elemental analyser at $1020^{\circ} \mathrm{C}$, and carbon and nitrogen isotopic composition measured on a DeltaPlus (Finnigan MATT) continuous flow, isotope ratio mass spectrometer. Stable isotope ratios are reported in standard delta $(\delta)$ notation per mil $(\%)$ as: $\delta X=\left[\left(R_{\text {sample }} / R_{\text {standard }}\right)\right.$ - 1] $\times 10^{3}$, where $X$ is ${ }^{13} \mathrm{C}$ or ${ }^{15} \mathrm{~N}$ and $R={ }^{13} \mathrm{C} /{ }^{12} \mathrm{C}$ or ${ }^{15} \mathrm{~N} /{ }^{14} \mathrm{~N}$, respectively. Standard reference materials are PDB limestone for carbon (a calibrated working standard of $\mathrm{CO}_{2}$ gas was used), and air was the standard for nitrogen (a calibrated working standard of $\mathrm{N}_{2}$ gas was used).

Water samples were analysed for total $\mathrm{NH}_{4}-\mathrm{N}$, nitrate + nitrite nitrogen $\left(\mathrm{NO}_{3}-\mathrm{N}\right)$, dissolved reactive phosphorus (DRP) and total phosphorus (TP) using the standard methods of Grasshoff et al. (1983) on an AlphKem series 500 air-segmented continuous flow marine auto-analytical system.

Atrina excretion was estimated from the increase in $\mathrm{NH}_{4}-\mathrm{N}$ in the incubation chamber water and calculated as a rate in $\mathrm{mg} \mathrm{h}^{-1}$. The change in nutrient concentration, and the volume and area of the benthic chambers, were used to calculate the sediment nutrient efflux rates in $\mu \mathrm{mol} \mathrm{m} \mathrm{m}^{-2} \mathrm{~h}^{-1}$. These results were corrected for any control bottle changes (water column effects without sediment) and compensation water inputs. These results are regarded as net rates of exchange between sediment and water after denitrification and microphytobenthos uptake of nutrients released from the sediments.

As only 1 Atrina was enclosed in each treated chamber and the control chamber was within $4 \mathrm{~m}$ of the treated chamber, it is reasonable to assume that differences between the control and treated chambers will be mostly due to the presence of the Atrina and its associated infaunal and floral community. Consequently, the differences attributable to the presence of the Atrina have been estimated by subtracting the control from the treated chamber results. These have been compared with the Atrina respiration and excretion results.

Statistics. Paired $t$-tests were conducted to determine whether the effect of Atrina was consistent between sites and dates. However, it was anticipated that 
changes occurring along the turbidity gradient were a result of changes to Atrina behaviour. Information on the turbidity gradient in the harbour was available from a number of sources: measurements of suspended sediment concentrations made in January 2001, the attenuation coefficient calculated in February 2002 (adjusted to constant depth), and settling flux measurements in traps on a number of occasions from Ellis et al. (2002). Each of these was ranked from high to low and an average rank of turbidity derived for each site.

An analysis of covariance was undertaken to determine whether differences in $\mathrm{NO}_{3}-\mathrm{N}$ and $\mathrm{NH}_{4}-\mathrm{N}$ fluxes, respiration, and GPP among sites could be predicted by the turbidity gradient, and whether any relationship observed was consistent on the 2 dates (January 2001 and February 2002).

\section{RESULTS}

\section{Water column}

Water clarity (Fig. 2B) varied over the semi-diurnal tide with generally clearer water on the flood than ebb tides. The difference in clarity between flood and ebb tides was less than the clarity difference between sites at LB and JB than at UH, with $K_{\mathrm{d}}$ values of 0.58 to 0.53 , 0.48 to 0.64 , and 0.81 to 0.95 , respectively. At Site SL, water clarity varied considerably between phases of the tide with $K_{\mathrm{d}}$ values of 0.49 and 1.3 on the flood and ebb tides, respectively. Water clarity on the ebb tide at SL was lower than at the up-gradient site at UH, which is consistent with the observation of apparent bed scour at SL. The very much clearer water at SL than UH on the flood tide suggests that incoming oceanic water entrains or suspends a substantial load of sediment before reaching the $\mathrm{UH}$ site. It also indicates that Site SL is at the transition zone of the upper limit of clear water on the flood tide. Although less light reached the sediments at Sites UH and SL than at JB and LB (Fig. 2C), there was sufficient light for photosynthesis by microphytobenthos and phytoplankton at all sites.

Phytoplankton species composition was dominated by small flagellates and the diatom Chaetocerous sp. at the outer harbour sites. At the inner harbour sites, small flagellates were dominant. The diatom Pseudonitzschia seriata was found at all sites and the diatom Skeletonema sp. at the outer harbour sites only. In the benthos, there were few dinoflagellates. Communities were dominated by diatoms Gyrosigma spp. and Nitzschia spp., although Gyrosigma spp., a resuspendor, was present at low levels only in the 2 inner harbour sites. Phytoplankton biomass, as indicated by chlorophyll a concentrations, was highest at Site UH and decreased down the gradient to Site LB (Table 1). Initial and final concentrations in the light bottles incubated with the benthic chambers demonstrated rapid growth with chlorophyll concentrations increasing by 25 to $32 \%$ during the $5 \mathrm{~h}$ incubation period. There was essentially no growth in the dark bottles, as expected.

Water column chemistry down the estuarine turbidity gradient (Table 1) was essentially constant for DRP and $\mathrm{NH}_{4}-\mathrm{N}$ concentrations, while TP concentrations were higher in the inner harbour. This is consistent with the much higher phytoplankton biomass and turbidity at the inner harbour sites.

Table 1. Water chemistry and chlorophyll a concentrations in initial and final $5 \mathrm{~h}$ bottle incubations in February 2002 (data in square brackets refer to 2001). All results are expressed in $\mathrm{mg} \mathrm{m}^{-3}$. $\mathrm{NH}_{4}-\mathrm{N}$ : ammoniacal nitrogen; DRP: dissolved reactive phosphorus; TP: total phosphorus. Nitrate-nitrogen concentrations were below the detection level

\begin{tabular}{|lcccccc|}
\hline Site & \multirow{2}{*}{$\mathrm{NH}_{4}-\mathrm{N}$} & DRP & TP & \multicolumn{3}{c|}{$\begin{array}{c}\text { Chlorophyll } a \\
\text { Light }+5 \mathrm{~h}\end{array}$} \\
\hline $\mathrm{UH}$ & 9 & 7 & 28 & 2.7 & 3.6 & 2.8 \\
$\mathrm{SL}$ & $11[6]$ & $8[7]$ & 23 & $2.0[0.6]$ & 2.9 & 2.0 \\
$\mathrm{JB}$ & $10[7]$ & $7[8]$ & 17 & $0.9[0.6]$ & 1.9 & 1.5 \\
$\mathrm{LB}$ & $11[4]$ & $7[6]$ & 17 & $0.9[0.5]$ & 1.1 & 1.0 \\
\hline
\end{tabular}

Table 2. Atrina zelandica. Mean $(\mathrm{n}=3)$, net oxygen $\left(\mathrm{O}_{2}\right)$ respiration and ammoniacal nitrogen $\left(\mathrm{NH}_{4}-\mathrm{N}\right)$ excretion rates $\left(\mathrm{mg} \mathrm{h}^{-1}\right)( \pm \mathrm{SD})$ from 3 sites incubated in water from the same site (ambient) and Site UH (turbid). Results are corrected for controls. Measurements were made in January 2001

\begin{tabular}{|lcccc|}
\hline \multirow{2}{*}{ Site } & \multicolumn{2}{c}{$\mathrm{O}_{2}$ respiration } & \multicolumn{2}{c|}{$\mathrm{NH}_{4}$-N excretion } \\
& Ambient & Turbid & Ambient & Turbid \\
\hline SL & $-3.21(1.11)$ & $-3.80(0.81)$ & $0.099(0.046)$ & $0.219(0.110)$ \\
JB & $-1.89(0.89)$ & $-2.91(1.15)$ & $0.093(0.001)$ & $0.216(0.127)$ \\
LB & $-3.61(1.63)$ & $-2.91(0.98)$ & $0.100(0.052)$ & $0.224(0.120)$ \\
\hline
\end{tabular}


Atrina from all sites. Respiration results were more variable when suspended solids concentrations increased, with increases for Sites SL and JB, but a decrease for Site LB.

As only 1 Atrina was collected from each site in February 2002, measurements are only used as an indication of relative condition at the 4 sites (Table 3 ). Condition index (dry flesh wt divided by shell length, Ellis et al. 2002) was substantially greater at Site LB than at the other 3 sites. The separation of Atrina tissue into stomach, gonad, and other flesh shows a much larger mass of gonad material in the Atrina from Site LB, suggesting that the Atrina were preparing to spawn.

Elemental and stable isotope values in the sediments, Atrina faeces, and Atrina flesh (excluding gonad and stomach tissue) (Tables 4 \& 5) showed different patterns down the estuarine turbidity gradient. Sediment $\delta^{13} \mathrm{C}$ values show little indication of a terrigenous source (expected $\delta^{13} \mathrm{C}$ values $\approx-25$ to $-35 \%$ ) or influence from pelagic phytoplankton (expected $\delta^{13} \mathrm{C}$ values about $-22 \%$ ), suggesting that the organic com-

Table 3. Atrina zelandica. Morphology and condition. Condition index $=$ whole tissue dry wt divided by shell length

\begin{tabular}{|lcccccc|}
\hline Site & $\begin{array}{c}\text { Shell } \\
\text { length }(\mathrm{mm})\end{array}$ & Whole & $\begin{array}{c}\text { Tissue dry wt (g) } \\
\text { Stomach }\end{array}$ & Gonad & Flesh & $\begin{array}{c}\text { Condition } \\
\text { index }\end{array}$ \\
\hline UH & 236 & 6.162 & 0.105 & 0.480 & 5.577 & 0.026 \\
SL & 250 & 5.495 & 0.049 & 0.332 & 5.114 & 0.022 \\
JB & 210 & 5.928 & 0.080 & 0.388 & 5.460 & 0.028 \\
LB & 213 & 8.873 & 0.153 & 1.088 & 7.632 & 0.042 \\
\hline
\end{tabular}

Table 4. Atrina zelandica. Faeces, flesh, and sediment carbon (C) and nitrogen (N) content (\%), and C:N ratios

\begin{tabular}{|lcccccccccc|}
\hline Site & \multicolumn{3}{c}{$\begin{array}{c}\text { Carbon } \\
\text { Sed. Faeces Flesh }\end{array}$} & \multicolumn{3}{c}{ Nitrogen } & \multicolumn{3}{c|}{ C:N ratio } \\
& Sed. Faeces Flesh & \multicolumn{3}{c}{ Sed. Faeces Flesh } \\
\hline UH & 1.07 & 0.67 & 38.34 & 0.09 & 0.06 & 9.49 & 11.89 & 11.17 & 4.10 \\
SL & 0.99 & 0.74 & 39.63 & 0.08 & 0.08 & 6.76 & 13.20 & 9.87 & 5.86 \\
JB & 0.60 & 0.95 & 40.86 & 0.05 & 0.08 & 6.67 & 11.32 & 11.88 & 6.13 \\
LB & 0.76 & 0.60 & 39.44 & 0.05 & 0.07 & 5.51 & 16.89 & 9.23 & 7.16 \\
\hline
\end{tabular}

Table 5. Atrina zelandica. Carbon and nitrogen natural abundance stable isotope composition (\%) of sediment, Atrina faeces, and Atrina flesh (excluding gonad and stomach tissue)

\begin{tabular}{|lcccccc|}
\hline \multirow{2}{*}{ Site } & \multicolumn{3}{c}{ Carbon $\left(\delta^{13} \mathrm{C}\right)$} & \multicolumn{3}{c|}{ Nitrogen $\left(\delta^{15} \mathrm{~N}\right)$} \\
& Sediment & Faeces & Flesh & Sediment & Faeces & Flesh \\
\hline UH & -17.72 & -20.94 & -20.56 & 6.91 & 6.22 & 9.57 \\
SL & -15.37 & -21.15 & -19.14 & 7.35 & 7.67 & 10.69 \\
JB & -16.97 & -21.46 & -19.71 & 6.43 & 6.66 & 10.60 \\
LB & -10.41 & -16.62 & -19.37 & 6.30 & 7.08 & 11.21 \\
\hline
\end{tabular}

ponent was not recent and the carbon may have been recycled several times. Whereas \% $\mathrm{C}$ in the sediments to decrease down-gradient, the sediment $\delta^{13} \mathrm{C}$ ( of the Te Kapa inlet. This level of ${ }^{13}$ enrichment indithat site.

For nitrogen, both the $\% \mathrm{~N}$ and $\delta^{15} \mathrm{~N}$ values in the sediments decreased down-gradient, with lowest values at Site LB. Although there was no apparent relationship with distance down-gradient associated with the variability in the $\% \mathrm{C}$ in the Atrina flesh, there was a consistent decline in the \% N content. Consequently, there was a marked increase in the $\mathrm{C}: \mathrm{N}$ ratios in the Atrina flesh down-gradient (Table 4).

Although there were small differences between sites for the $\delta^{13} \mathrm{C}$ values in the Atrina flesh (range -19.14 to $-20.56 \%$ o) with greatest enrichment $(-19.14 \%$ o) at SL, there was a small but consistent increase in $\delta^{15} \mathrm{~N}$ enrichment (from 9.57 to $11.21 \%$ ) down-gradient. This enrichment pattern suggests increasing levels of microbial processing, including mineralisation and denitrification, down the estuarine gradient. With respect to the Atrina faeces, the $\delta^{13} \mathrm{C}$ and $\delta^{15} \mathrm{~N}$ values were depleted below flesh values ( 0.4 to 2.1 and 3.0 to $4.1 \%$, respectively), which is comparable with 1 'trophic' level'1. However, whereas the $\delta^{15} \mathrm{~N}$ values of the faecal material were comparable with those of the ambient sediments, the $\delta^{13} \mathrm{C}$ values of the faecal material were also substantially depleted (3.2 to $6.2 \%$ ) relative to the sediments in which the Atrina lived. This suggests that the Atrina fed on seston drifting down the estuary, as found by Riera \& Richard (1996), rather than resuspended from local sediments. At Site LB, the more enriched $\delta^{13} \mathrm{C}$ signatures in the sediments and faecal material suggest that the Atrina were feeding on locally resuspended material. However, as the $\delta^{13} \mathrm{C}$ enrichment of the flesh was not as great as would be expected relative to the sediments on a proportional basis from the other sites, it is possible that

\footnotetext{
${ }^{1} \mathrm{~A}$ trophic level in natural stable isotopic abundance is ca. $1 \%$ for $\delta^{13} \mathrm{C}$ and ca. $4 \%$ for $\delta^{15} \mathrm{~N}$. It is the level of isotopic fractionation that normally occurs when food passes through 1 transfer process in the food web
} 
the isotopic data reflect a recent change in Atrina food source at Site LB.

\section{Sediments}

Sediment \% organic or seston contents (Table 6) were similar at Sites UH and SL at 3.48 and $3.59 \%$, respectively, but much lower at Sites JB and LB at 2.29 and $2.87 \%$, respectively. The mean \% C content of the sediments followed a similar pattern and there was a strong correlation $\left(\mathrm{p}<0.001, \mathrm{r}^{2}=0.902\right.$, $\mathrm{n}=8$ ) between the mean \% organic and the mean \% $\mathrm{C}$ content of the sediments. As the $\% \mathrm{~N}$ content of the sediments also appears to decrease while the $\mathrm{C}: \mathrm{N}$ ratio increases (Table 4), this suggests that biological processing is increasing down the estuarine gradient.

Sediment chlorophyll a concentrations (Table 6) did not follow the pattern of \% organics or \% C, with highest values being found at Sites UH and JB at 8.53 and $8.38 \mu \mathrm{g} \mathrm{g}^{-1}$ sediment, respectively. Chlorophyll a concentrations were lower at LB (6.49 $\mu \mathrm{g} \mathrm{g}^{-1}$ sediment) and lowest at Site SL (4.26 $\mu \mathrm{g} \mathrm{g}^{-1}$ sediment). The lower chlorophyll a values at SL and LB did not correlate with light, LB having the highest percentage of incident surface irradiance at the sediment surface $(23.5 \%)$ and SL the lowest (ca. 3.5\%). Whereas bed scouring may account for the low light levels at Site SL, scouring seems less likely at Site LB, although it is possible. These data suggest that there is higher grazing pressure at Site LB than the other 3 sites.

The treated minus control chamber data for the light incubations show a consistent pattern of less algal biomass in the treated than control chamber sediments (Fig. 3). This may indicate filtration by Atrina and subsequent burial by faeces and pseudofaeces and/or higher grazing pressure by the infauna attracted to the habitat created by Atrina. There was also a spatial distribution of less algal biomass in the inner than outer harbour Atrina beds. As Atrina pseudofaeces production rates are substantially greater in the more turbid inner than clearer outer harbour, this suggests that the burial of the microphytobenthos may be an important process.

\section{Benthic fluxes}

Estimates of benthic respiration, benthic gross primary production (GPP), and BNF are made from the oxygen and nutrient data collected in February 2002 and, where possible, compared with similar data collected in January 2001.

\section{Oxygen}

Benthic respiration is the sediment oxygen demand (SOD) measured in the dark chambers (Fig. 4A). Benthic respiration rates on Day 2 ranged from -0.70 to -2.13 and -2.02 to $-3.90 \mathrm{mmol}$ oxygen $\mathrm{m}^{-2} \mathrm{~h}^{-1}$ in the control and treated chambers, respectively. While variability in benthic respiration occurred down the estuarine turbidity gradient, these results indicate consistently higher benthic respiration in the Atrina beds than in the adjacent bare sediments on all days (paired $t$-test $\mathrm{p}=0.0292$ ).

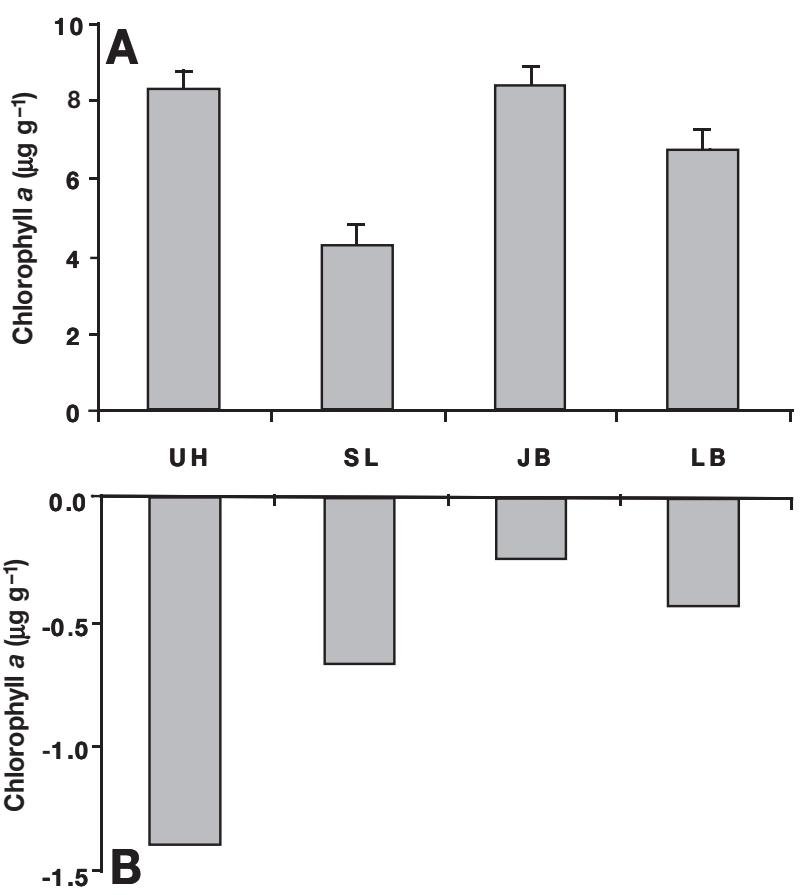

Fig. 3. (A) Average microphytobenthos biomass, as indicated by chlorophyll a $\left(\mu \mathrm{g} \mathrm{g}^{-1}+\mathrm{SE}\right)$, from all chambers at each site. (B) Net microphytobenthos biomass difference in light chambers at each site calculated as treated minus control chlorophyll a concentrations. Negative values indicate there was lower biomass in the treated than in the control chamber 


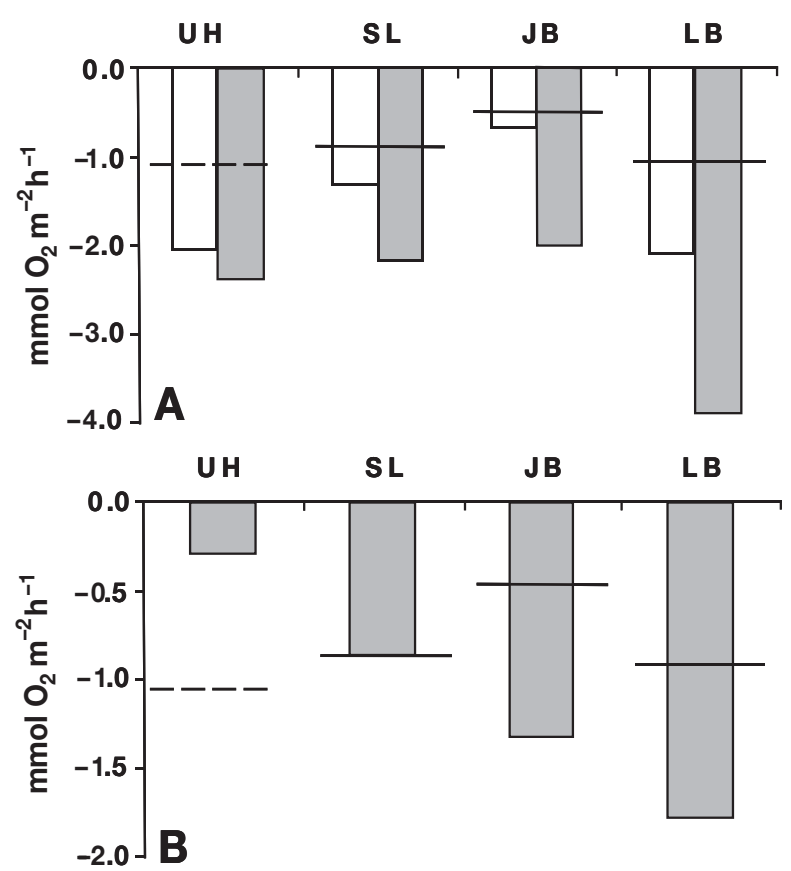

Fig. 4. Atrina zelandica. (A) Benthic respiration in the control ( $\square$ ) and treated $(\square)$ chambers at each site, with an estimate for Site UH (-- ) and measured (-) areal equivalent Atrina respiration calculated from the Atrina respiration results at 4 Atrina $\mathrm{m}^{-2}$ (Table 2). (B) Net benthic respiration difference due to the presence of Atrina, calculated as treated minus control benthic respiration at each site. Maximum areal equivalent Atrina respiration is indicated as for (A). As benthic respiration is an oxygen demand, the negative results mean that there is greater benthic respiration in the treated than in the control chamber

The difference between treated and control chambers (Fig. 4B) includes direct Atrina respiration equivalent to benthic respiration rates of -0.54 to $-1.08 \mathrm{mmol}$ oxygen $\mathrm{m}^{-2} \mathrm{~h}^{-1}$, calculated from the incubation results at a nominal population density of $4 \mathrm{~m}^{-2}$ (i.e. 1 Atrina per benthic chamber) (Table 2). However, while Atrina respiration could account for the difference at the 2 inner harbour sites (UH and SL), it could not account for all of the benthic respiration at the 2 outer harbour sites (JB and LB), suggesting that some other aspect of the Atrina presence may be important.

As expected, photosynthetic oxygen production occurred in the light chambers at each site and generally exceeded benthic respiration in the outer harbour sites where a higher percentage of surface irradiance reached the sediments. The difference between light and dark chamber response is assumed to be due to benthic GPP (Fig. 5A). Benthic GPP rates ranged from 1.29 to 3.35 and 0.44 to $4.17 \mathrm{mmol}$ oxygen $\mathrm{m}^{-2} \mathrm{~h}^{-1}$ in the control and treated chambers, respectively. Overall, no consistent significant difference was observed between GPP in bare sediment and sediment with Atrina. However, a shift from less to more benthic
GPP in the treated than control chambers was observed down the estuarine gradient (Fig. 5B, $\mathrm{r}^{2}=$ $0.86, p=0.041$ using ranks given in Table 6). This difference includes the direct respiration effect of Atrina and is consistent with greater burial of microphytobenthos within the Atrina beds in the inner harbour where pseudofaeces production rates are likely to be higher than in the outer harbour.

\section{Nutrients}

Benthic nutrient fluxes of DRP, TP, $\mathrm{NH}_{4}-\mathrm{N}, \mathrm{NO}_{3}-\mathrm{N}$, and dissolved inorganic N (DIN) (Table 7) were almost always higher in the dark than in the light chambers, and in the treated than in the control chambers at all sites. Significant differences between chambers with Atrina and bare chambers were found for fluxes of TP and DIN in the dark for all data (paired $t$-test $\mathrm{p}=0.0463$ and 0.0083 , respectively). Significant differences were also found in the light, with DIN, $\mathrm{NH}_{4}-\mathrm{N}$ and $\mathrm{NO}_{3}-\mathrm{N}$ fluxes differing between chambers, with Atrina and bare chambers (paired $t$-test $\mathrm{p}=0.0033,0.0103$ and 0.0414 , respectively). The light-dark results are consistent with light mediation of BNF through uptake of the released nutrients by microphytobenthos at the sediment-water interface. The differences seen between the treated and control chamber results are due to the presence of the single Atrina in the treated chambers, and include excretion of $\mathrm{NH}_{4}-\mathrm{N}$ by the Atrina (Table 2), as well as the effect of differences in the local infaunal abundance and microbial activity at each site.

The differences between treated and controls, seen in the DRP and TP data (Table 7), were relatively small, in the range of -1.7 to $7.5 \mu \mathrm{mol}$ DRP $\mathrm{m}^{-2} \mathrm{~h}^{-1}$ and -4.6 to $7.9 \mu \mathrm{mol} \mathrm{TP} \mathrm{m}^{-2} \mathrm{~h}^{-1}$, with much of the TP difference due to the DRP component. In the light, the DRP and TP efflux from the treated chambers was consistently higher than the control for the inner 3 sites, but lower than the control at Site LB. In addition, the dark DRP and TP efflux relative to control tended to decline down-gradient for the inner 3 sites but was substantially higher at Site LB. This could not, however, be tested for statistical significance.

For DIN data (Fig. 6), the differences between treated and controls were mainly due to the $\mathrm{NH}_{4}-\mathrm{N}$ component, which ranged from 5 to $81 \mu \mathrm{mol} \mathrm{m}^{-2} \mathrm{~h}^{-1}$ in the light (Fig. 6A), and from 22 to $146 \mu \mathrm{mol} \mathrm{m}^{-2} \mathrm{~h}^{-1}$ in the dark (Fig. 6B). The positive values indicate a greater efflux in the Atrina beds than in the adjacent bare sediments. Indications of the likely contribution from direct Atrina $\mathrm{NH}_{4}-\mathrm{N}$ excretion were estimated from the excretion experiment results (Table 2) at a population density of $4 \mathrm{~m}^{-2}$. As there was higher 

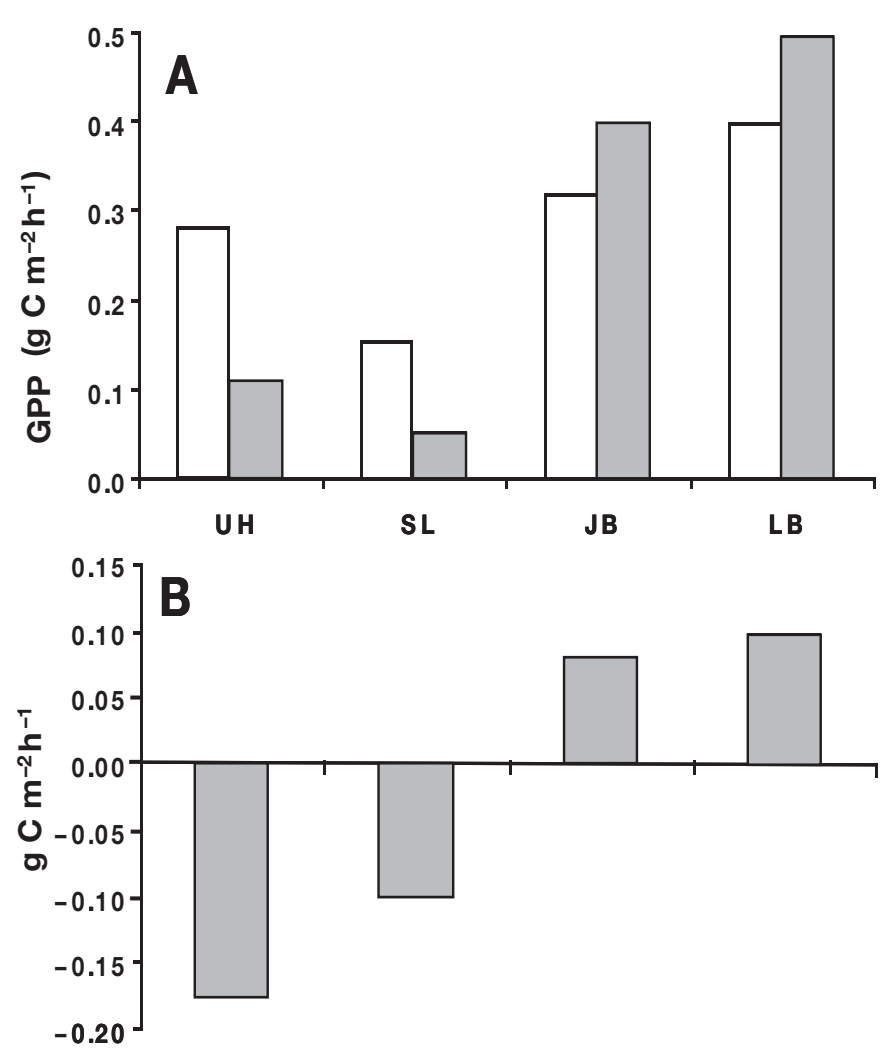

Fig. 5. (A) Benthic gross primary production (GPP) in the control ( $\square$ ) and treated $(\square)$ chambers at each site. (B) Net benthic GPP difference due to the presence of 1 Atrina, calculated as treated minus control benthic GPP at each site. Negative values indicate greater GPP in the control chambers; positive values indicate greater GPP in the treated chambers

Table 7. Atrina zelandica. Excretion rates with ambient water 'A. (site)' and upper harbour water ' $A$. (UH)' as mean areal equivalent values at a density of $4 \mathrm{~m}^{-2}$, compared with benthic nutrient fluxes $\left(\mu \mathrm{mol} \mathrm{m} \mathrm{m}^{-2} \mathrm{~h}^{-1}\right)$ in the control (C) and treated (T), light (L) and dark (D) chamber pairs at the 4 sites along the turbidity gradient. DRP: dissolved reactive phosphorus; TP: total phosphorus; $\mathrm{NH}_{4}-\mathrm{N}$ : ammoniacal nitrogen $(\mathrm{N}) ; \mathrm{NO}_{3}-\mathrm{N}$ : nitrate + nitrite $\mathrm{N}$; DIN: dissolved inorganic $\mathrm{N}$

\begin{tabular}{|lcccccccccc|}
\hline \multirow{2}{*}{ Site } & \multicolumn{2}{c}{ DRP } & \multicolumn{2}{c}{ TP } & \multicolumn{2}{c}{$\mathrm{NH}_{4}-\mathrm{N}$} & \multicolumn{2}{c|}{$\mathrm{NO}_{3}-\mathrm{N}$} & \multicolumn{2}{c}{$\mathrm{DIN}$} \\
& $\mathrm{C}$ & $\mathrm{T}$ & $\mathrm{C}$ & $\mathrm{T}$ & $\mathrm{C}$ & $\mathrm{T}$ & $\mathrm{C}$ & $\mathrm{T}$ & $\mathrm{C}$ & $\mathrm{T}$ \\
\hline $\mathrm{UH}(\mathrm{D})$ & 4.3 & 7.4 & 17.8 & 23.3 & 88.4 & 110.2 & 23.1 & 23.1 & 111.6 & 133.3 \\
$\mathrm{UH}$ (L) & 2.5 & 7.4 & 16.6 & 22.1 & 20.4 & 69.4 & 6.8 & 32.7 & 27.2 & 102.0 \\
SL (D) & 6.5 & 6.5 & 16.1 & 19.4 & 71.4 & 95.7 & 25.7 & 58.6 & 97.1 & 154.3 \\
SL (L) & 1.3 & 6.5 & 19.4 & 21.9 & 12.9 & 94.3 & 10.0 & 31.4 & 22.9 & 125.7 \\
A. (SL) & & & & & & 28.3 & & & & \\
A. (UH) & & & & & & 62.5 & & & & \\
JB (D) & 4.9 & 4.2 & 13.3 & 14.7 & 28.0 & 99.4 & 7.8 & 21.7 & 35.7 & 121.1 \\
JB (L) & 2.1 & 6.3 & 14.7 & 22.4 & 28.0 & 40.4 & 4.7 & 10.9 & 32.6 & 51.2 \\
A. (JB) & & & & & & 26.7 & & & & \\
A. (UH) & & & & & & 61.7 & & & & \\
LB (D) & 5.4 & 13.1 & 18.4 & 26.1 & 57.8 & 204.1 & 6.8 & 22.1 & 64.6 & 226.2 \\
LB (L) & 6.1 & 4.6 & 19.2 & 14.6 & 37.4 & 42.5 & 6.8 & 17.0 & 44.2 & 59.5 \\
A. (LB) & & & & & & 28.7 & & & & \\
A. (UH) & & & & & & 64.2 & & & & \\
\hline
\end{tabular}

turbidity at the 2 inner harbour sites (UH and SL), it is likely that Atrina $\mathrm{NH}_{4}-\mathrm{N}$ excretion rates would be higher there than in the clearer outer harbour sites (JB and LB) (Fig. 6). However, Atrina $\mathrm{NH}_{4}-\mathrm{N}$ excretion rates may fluctuate between these levels at Site SL with the transition from clear to turbid water on the flood and ebb tide, respectively.

Similar results were found for the nitrogen fluxes on both sampling days (although these were separated by a year) and spatial variability in the difference in fluxes generated by Atrina frequently appeared linked to the turbidity gradient in the harbour. ANCOVA analysis found no significant difference in the response of Atrina-generated benthic flux to turbidity between years (year $\times$ turbidity interaction $\mathrm{p}>0.15$ for all variables light or dark) with DIN and $\mathrm{NH}_{4}-\mathrm{N}$ fluxes in the dark being predictable by turbidity $(\mathrm{p}=0.0045$ and 0.0298 , respectively). There were also indications of a significant relationship with turbidity for $\mathrm{NH}_{4}-\mathrm{N}$ in the light, although this was less of a gradient relationship than a difference between inner and outer estuary sites (Wilcoxon test $\mathrm{p}=0.0558$ ). All other relationships were non-significant $(\mathrm{p}>0.10)$.

In the light (Fig. 6A), the greater efflux of $\mathrm{NH}_{4}-\mathrm{N}$ at the inner than outer harbour sites may reflect the lower percentage of surface incident light reaching the sediments at those sites, and hence, less uptake by microphytobenthos. The net $\mathrm{NH}_{4}-\mathrm{N}$ efflux increase attributable to the presence of Atrina, as estimated from the benthic chambers, is in good agreement with the likely Atrina $\mathrm{NH}_{4}-\mathrm{N}$ excretion rates, estimated from Atrina excretion incubations. In the outer harbour sites, the $\mathrm{NH}_{4}-\mathrm{N}$ efflux, estimated from the benthic chambers, was smaller than the likely Atrina $\mathrm{NH}_{4}-\mathrm{N}$ excretion rates, indicating a large sediment nitrogen demand, probably from the microphytobenthos in the higher light environment (e.g. Sundbäck et al. 2004).

In the dark (Fig. 6B), benthic chamber results showed a smaller net efflux of $\mathrm{NH}_{4}-\mathrm{N}$ than the likely Atrina $\mathrm{NH}_{4}-\mathrm{N}$ excretion rates at the inner harbour sites, but a much greater net efflux than the likely Atrina $\mathrm{NH}_{4}-\mathrm{N}$ excretion rates at the outer harbour sites. A similar pattern was observed in the preliminary experimental results in 2001 (Fig. 6B). While the reduction in microphytobenthos nutrient uptake in the dark would account for the outer harbour results, the inner harbour results may indicate some changes in biogeochemical processes within the sediments (e.g. Anderson et al. 2003). 

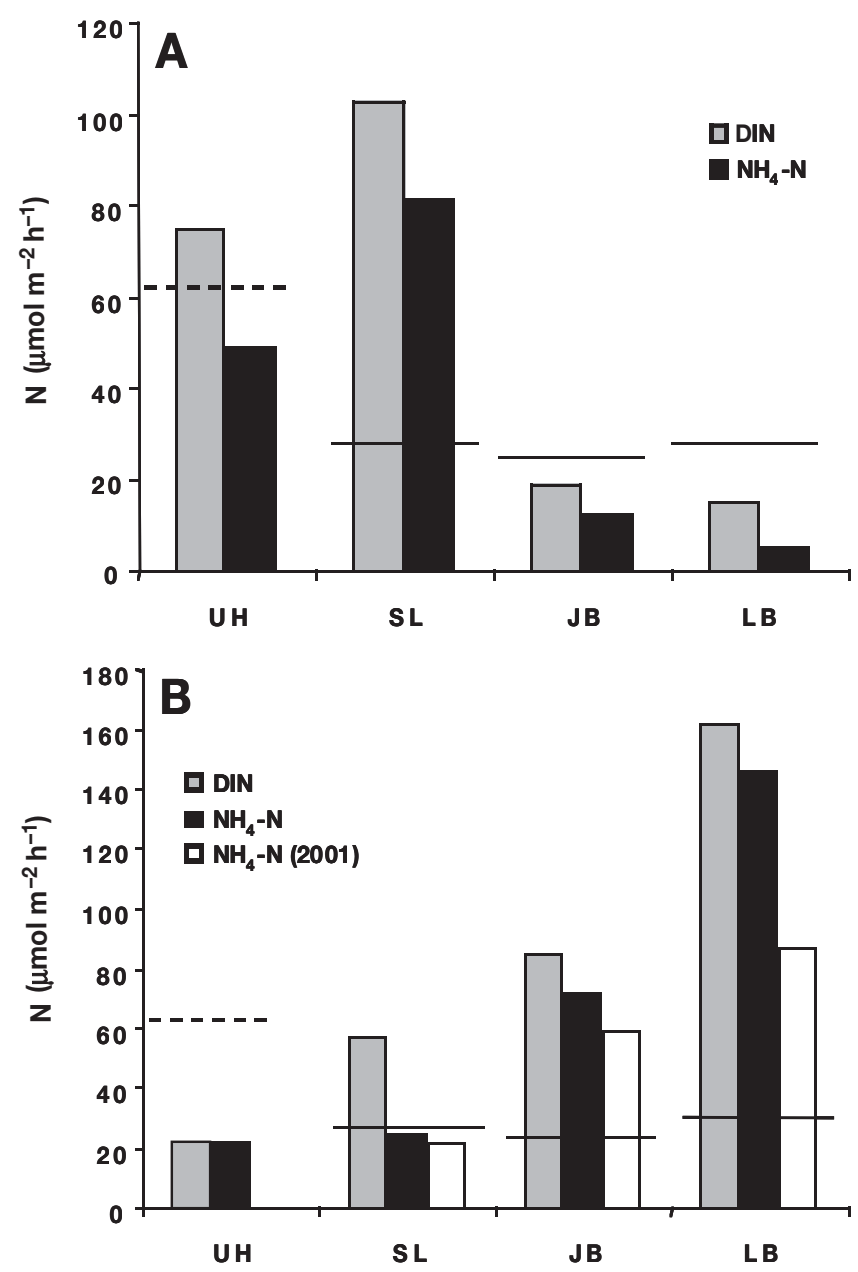

Fig. 6. Net effect of the presence of Atrina zelandica on the dissolved inorganic nitrogen (DIN) and ammoniacal nitrogen $\left(\mathrm{NH}_{4}-\mathrm{N}\right)$ effluxes (A) in the light, and (B) in the dark chambers at each site. Dark $\mathrm{NH}_{4}-\mathrm{N}$ effluxes measured in 2001 show a similar pattern to the 2002 results. Differences calculated as treated minus control efflux rates at each site. Likely equivalent areal Atrina $\mathrm{NH}_{4}-\mathrm{N}$ excretion rates estimated for Site UH (---) and as a measure for the other 3 sites (- - , calculated from the excretion incubation results (Table 2) for a density of 4 Atrina $\mathrm{m}^{-2}$

The presence of a $\mathrm{NO}_{3}-\mathrm{N}$ efflux in the chambers indicates that some of the $\mathrm{NH}_{4}-\mathrm{N}$ released from the sediments was being nitrified. This also implies that denitrification rates were less than nitrification rates. The differences, relative to controls, seen in the $\mathrm{NO}_{3}-\mathrm{N}$ data (Fig. 7) show a consistent pattern of greater nitrification in the treated than control chambers, except at Site UH in the dark, where the nitrification rates were the same.

Whereas the $\mathrm{NO}_{3}-\mathrm{N}$ component is about 10 to $25 \%$ of the DIN efflux, an estimate of the absolute DIN efflux cannot be made as we made no measurement of denitrification rates. The apparent decrease in $\mathrm{NO}_{3}-\mathrm{N}$ component down the estuarine gradient cannot be interpreted as reduced nitrification rates as it could also indicate a faster denitrification rate and, thus, less of the nitrified $\mathrm{NH}_{4}-\mathrm{N}$ would remain in the water column as free $\mathrm{NO}_{3}-\mathrm{N}$. However, a consequence of faster denitrification rates would be an overall reduction in the total nitrogen in the sediments down the estuarine gradient and this is seen in the \% $\mathrm{N}$ data (Tables 4 \& 6).

\section{DISCUSSION}

The results from this study indicate that there are potentially large differences between the BNF from beds of the pinnid bivalve Atrina zelandica and the adjacent bare sediments, as well as differences along the turbidity gradient in Mahurangi Harbour. Our results indicate a step-wise change in the effects of suspended solids concentrations between the 2 inner and 2 outer harbour sites rather than a continuous gradient downstream. What are the likely causes of these differences and what is the effect of the presence of Atrina beds on the nutrient supply to this harbour?

Nutrient supply to Mahurangi Harbour is from land, via stream inflows and surface runoff, the coastal water outside the harbour, via tidal exchange, and mineralisation of accumulated sediment and suspended solids within the harbour as BNF. Indications of nutrient supply from land drainage and BNF versus tidal exchange can be seen in the water column nutrient data (Table 1), which show a decline in $\mathrm{NH}_{4}-\mathrm{N}$ and TP from the inner to outer harbour. The implication being that tidal exchange from the coastal waters in summer is nutrient-deficient as seen elsewhere around the New Zealand coast (e.g. Gibbs \& Vant 1997, Zeldis 2004). The BNF and land drainage origin of the watercolumn nutrients is also implied by the chlorophyll $a$ concentrations, which increased by about $1 \mathrm{mg} \mathrm{m}^{-3}$ in the light bottles over the $5 \mathrm{~h}$ incubation at the 3 inner harbour sites, and substantially less at the harbour entrance (Table 1).

The release of nutrients from the sediments, following mineralisation, occurs throughout the harbour, and the observed nutrient concentration differences between sites may be a function of differential dilution of BNF as the water becomes deeper towards the harbour entrance. Sequestering by microphytobenthos may also have a spatial effect as has been seen in estuaries and fjords elsewhere (e.g. Sundbäck et al. 2004), although there was little spatial difference in microphytobenthos species composition or biomass, which averaged ca. $6.8 \mu \mathrm{g}$ chlorophyll $\mathrm{a} \mathrm{g}^{-1}$ across the 4 sites. This is equivalent to ca. $85 \mathrm{mg}$ chlorophyll $\mathrm{a} \mathrm{m}^{-2}$ and is comparable with the average benthic biomass of $97.5 \mathrm{mg}$ chlorophyll $\mathrm{a} \mathrm{m}^{-2}$ in summer for the sediments 


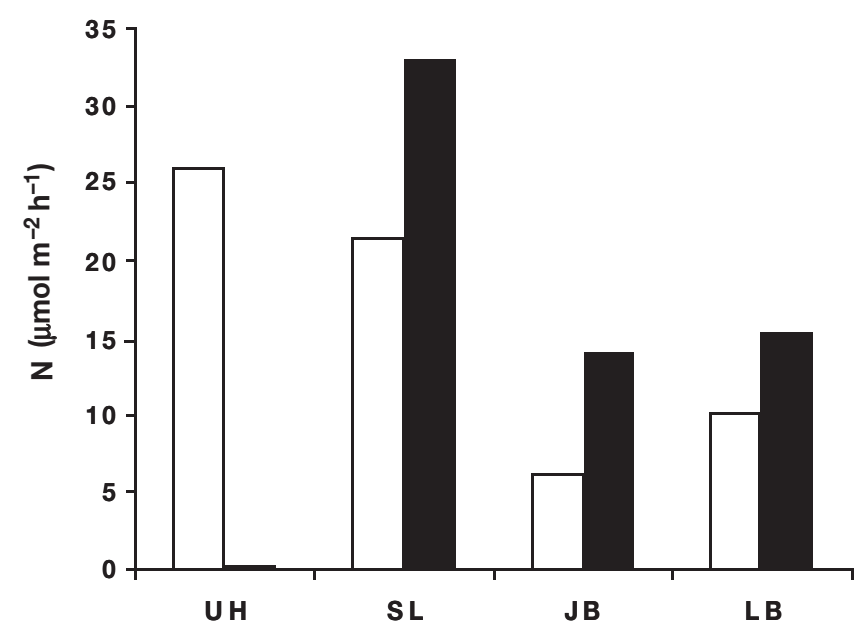

Fig. 7. Net effect of the presence of Atrina zelandica on the nitrate + nitrite nitrogen $\left(\mathrm{NO}_{3}-\mathrm{N}\right)$ efflux in the light $(\square)$ and dark ( $\square$ ) chambers at each site

of nearby Manukau Harbour (Cahoon \& Safi 2002), but is at the higher end of the range (11 to $102 \mathrm{mg}$ chlorophyll $\mathrm{a} \mathrm{m}^{-2}$ ) reported in Gullmar Fjord, Sweden (Sundbäck et al. 2004).

While our in situ benthic chamber experiments examined the differences between bare sediment and sediment with Atrina, it is obvious that Atrina, which are suspension feeders, have a direct influence on water-column nutrient dynamics independent of sediment nutrient release. The laboratory respiration and excretion incubations demonstrated that, while the respiration of an individual Atrina, at 0.5 to $1.0 \mathrm{mg}$ oxygen $\mathrm{h}^{-1}$ in summer, was only slightly affected by changes in suspended solids concentrations, their $\mathrm{NH}_{4}-\mathrm{N}$ excretion rates increased dramatically from about 0.1 to about $0.22 \mathrm{mg} \mathrm{h}^{-1}$ when exposed to the highly turbid inner harbour water, possibly associated with higher pseudofaeces production. This response to changes in suspended solids concentrations implies that Atrina can react quickly to changing environmental conditions.

A response to increased turbidity was also apparent in the benthic chamber results when looking at the net effect of the presence of Atrina (Fig. 6). At the more turbid inner harbour sites, the net $\mathrm{NH}_{4}-\mathrm{N}$ increase in the light chambers was comparable with Atrina excretion rates in turbid water, as measured in the laboratory incubations using similar water. This indicates that the apparent BNF increase at these sites was probably entirely attributable to Atrina excretion during the day. However, at the less turbid outer harbour sites, the net $\mathrm{NH}_{4}-\mathrm{N}$ increase in the light chambers was less than half the Atrina excretion rates measured in the laboratory incubations with similar water. This indicates that the sediments in the outer harbour are likely to be a sink for nutrient nitrogen from the water column in daylight, implying either enhanced uptake by microphytobenthos or microbial activity (e.g. denitrification) within the sediments.

Resolution of this issue is suggested from the dark chamber results (Fig. 6B). In contrast to the large net $\mathrm{NH}_{4}-\mathrm{N}$ increase in the light chambers at the turbid inner harbour sites, in the dark, the net $\mathrm{NH}_{4}-\mathrm{N}$ increase was substantially less than the Atrina excretion rates measured in the laboratory incubations. As Atrina excretion rates are unlikely to be affected by a change in light, the reduced $\mathrm{NH}_{4}-\mathrm{N}$ efflux in the dark at these sites implies an increase in nitrification and denitrification. Evidence of enhanced nitrification in the Atrina beds, especially at the inner harbour sites, can be seen in the net $\mathrm{NO}_{3}-\mathrm{N}$ efflux results (Fig. 7). Whereas the presence of $\mathrm{NO}_{3}-\mathrm{N}$ is a function of the balance between nitrification and denitrification, the absence of $\mathrm{NO}_{3}-\mathrm{N}$ in the benthic environment may indicate that denitrification rates exceed nitrification, rather than a lack of nitrification. Consequently, the loss of $\mathrm{NO}_{3}-\mathrm{N}$ at Site $\mathrm{UH}$ in the dark most likely indicates an increase in denitrification rate.

In the dark at the outer harbour sites, the increase in net $\mathrm{NH}_{4}-\mathrm{N}$ efflux relative to the light chamber results (Fig. 6) is consistent with there being little or no microphytobenthos nutrient uptake in the dark. This seems contrary to the recent findings of Anderson et al. (2003), who suggest that dark uptake by microphytobenthos is likely to be an important sink for mineralised N. Our results do not deny this possibility but imply that the true $\mathrm{N}$ mineralisation rate in Mahurangi Harbour sediments is much higher than the dark uptake rate, and the $\mathrm{NH}_{4}-\mathrm{N}$ efflux observed is a net excess. Our net $\mathrm{NH}_{4}-\mathrm{N}$ and $\mathrm{NO}_{3}-\mathrm{N}$ efflux results are comparable with the efflux rates measured in light and dark at the shallower depths in Gullmar Fjord in spring but are higher than those measured in late summer (Sundbäck et al. 2004).

As the dark net $\mathrm{NH}_{4}-\mathrm{N}$ efflux (treated minus control chamber results) at the outer harbour sites is substantially greater than the Atrina excretion rates, it is likely that most of the increase is due to differences in the sediment caused by the presence of the Atrina. The similar pattern of net $\mathrm{NH}_{4}-\mathrm{N}$ efflux in the dark, down the turbidity gradient, measured the previous summer indicates that this spatial difference is unlikely to be a transient feature.

Our results demonstrate that BNF are greater from Atrina beds than bare sediments in the clearer outer harbour waters at night. The marked difference between light and dark results, however, implies that nutrients released from organic decomposition and mineralisation within the sediments are being microbially (nitrification-denitrification) and biologically 
(microphytobenthos uptake in the light and dark) sequestered before reaching the overlying water column.

The results for the more turbid inner harbour sites are less obvious, although the high net $\mathrm{NH}_{4}-\mathrm{N}$ efflux in the light was attributable to Atrina excretion. Differences between light and dark may be associated with the higher rates of biodeposit (pseudofaeces) production by Atrina in turbid water (Ellis et al. 2002). The flow-on effect of higher biodeposit production is the potential to bury the microphytobenthos and reduce bioturbation. Previous studies in Mahurangi Harbour (Cummings et al. 1998, 2001, Ellis et al. 2000, Norkko et al. 2001, Hewitt et al. 2002) have demonstrated the effect of Atrina beds on increasing diversity, and changing community composition and functioning of the macrofauna (both as in- and epifauna). While the epibenthos affects the water column above the sediments, burrowing macrobenthos and infauna can impact on the nutrient dynamics within the sediments (Quijón et al. 1996, Gilbert et al. 1998, Newell et al. 2002). Some of these effects may be responsible for the spatial differences down the turbidity gradient seen in several of the other parameters measured.

Evidence of this can be seen in the GPP results (Fig. 5A), where GPP is lower in the Atrina beds than adjacent bare sediment at the inner harbour sites. This is consistent with burial by enhanced pseudofaeces production. As Atrina respiration rates measured in the laboratory incubations are equivalent to an areal sediment respiration rate of about $-0.12 \mathrm{~g} \mathrm{C} \mathrm{m}^{-2} \mathrm{~d}^{-1}$, most of the negative GPP at the inner harbour sites can be accounted for by Atrina respiration (Fig. 5B). This is consistent with the net $\mathrm{NH}_{4}-\mathrm{N}$ efflux being accounted for by Atrina excretion. Burial by pseudofaeces would account for the small decrease in estimated microphytobenthos biomass in the Atrina beds relative to the adjacent bare sediments at these sites. In contrast, at the outer harbour sites, positive net $\mathrm{GPP}^{2}$ rates indicate a substantial increase in microphytobenthos biomass in the Atrina beds relative to adjacent bare sediments. However, this is not consistent with the net microphytobenthos biomass estimates, which indicate a slight biomass decrease in the Atrina beds relative to adjacent bare sediments at these sites. Consequently, as there was no apparent difference in the species composition of microphytobenthos, the additional GPP is likely to reflect the production due to photosynthesis by epibenthos within the Atrina beds.

While epibenthos may photosynthesise, they are unlikely to alter the nutrient efflux leaving the sediments because they may not be in contact with those

${ }^{2}$ Note that the net GPP rates at the outer harbour sites include the Atrina respiration equivalent of $-0.12 \mathrm{~g} \mathrm{C} \mathrm{m}^{-2} \mathrm{~d}^{-1}$ sediments. However, they may uptake those nutrients from the water column within the benthic chamber. This means that the degree of GPP increase in the Atrina bed relative to adjacent bare sediment may reflect the confinement of nutrients within the benthic chambers, nutrients which might otherwise have dispersed into the overlying water. Our data show the likely epibenthos GPP to be 0.15 to $0.2 \mathrm{~g} \mathrm{C} \mathrm{m}^{-2} \mathrm{~d}^{-1}$ for an uptake of about $0.5 \mathrm{mmolN} \mathrm{m} \mathrm{N}^{-1} \mathrm{~d}^{-1}$ giving a C:N ratio in the order of 21 to 28.5. As C:N ratios for attached macroalgae are in the order of 20 , this uptake is consistent with epibenthos growth, which could account for the additional nutrient loss in the light chambers.

There was 35\% less organic matter in the outer than inner harbour sediments and a similar reduction in $\mathrm{C}$ and $\mathrm{N}$ content (Table 6). This suggests either less sedimentation or greater removal by microbial activity in the outer harbour sediments. Stable isotopic composition of the sediments suggest substantial ${ }^{13} \mathrm{C}$ enrichment in the outer harbour sediments relative to the inner harbour (Table 5), which indicates greater or faster microbial processing. The apparent reduction in organics content may, thus, be attributable to microbial activity. The enhanced nutrient release within the Atrina beds at the outer harbour sites would also be consistent with higher bioturbation and infaunal abundance.

While it is not possible to produce a full nutrient budget for Mahurangi Harbour from the data available, we can produce an estimate of the potential effect of the

Table 8. Simple nutrient budget used to estimate the relative importance of Atrina zelandica beds to the water column nutrient supply for primary production. Efflux values are net, and include the effects of coupled nitrification-denitrification and uptake by benthic microphytes. Sediment areas are estimated from Hewitt et al. (2002)

\begin{tabular}{|c|c|c|c|}
\hline & & \multicolumn{2}{|c|}{ Sediment area $\left(\mathrm{km}^{2}\right)$} \\
\hline & & Turbid zone & Clear zone \\
\hline Bare sediment & & 14 & 4 \\
\hline Atrina beds & & 2 & 5 \\
\hline \multicolumn{4}{|c|}{ Net DIN efflux (kg N) } \\
\hline \multirow[t]{2}{*}{ Bare sediment } & $\left(\right.$ day $\left.^{\mathrm{a}}\right)$ & 70 & 30 \\
\hline & $\left(\right.$ night $\left.^{\mathrm{a}}\right)$ & 200 & 30 \\
\hline \multirow[t]{2}{*}{ Atrina beds } & $\left(\right.$ day $\left.^{a}\right)$ & 230 & 280 \\
\hline & $\left(\right.$ night $\left.^{\mathrm{a}}\right)$ & 195 & 585 \\
\hline \multicolumn{4}{|c|}{ Net nutrient supply to Mahurangi Harbour } \\
\hline & & $\operatorname{Mass}\left(\mathrm{kg} \mathrm{N} \mathrm{d}^{-1}\right)$ & $\%$ Total \\
\hline River inflow (est.) & & 3.5 & 0.2 \\
\hline Bare sediment & & 330 & 20.3 \\
\hline Atrina beds & & 1290 & 79.5 \\
\hline 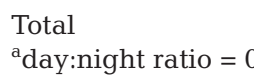 & 0.4 & 1623.5 & \\
\hline
\end{tabular}


Atrina beds on the nutrient supply (Table 8) and, thus, the relative importance of Atrina to the nutrient supply for primary production within the harbour. If we assume an Atrina density of $20 \mathrm{~m}^{-2}$ for about $7 \mathrm{~km}^{2}$ of outer harbour, based on the spatial distribution and abundance map of Hewitt et al. (2002), and a direct proportional increase in the light and dark BNF rates from 4 Atrina $\mathrm{m}^{-2}$ (Table 7 ), and a summer river inflow of about $3.5 \mathrm{~kg} \mathrm{DIN} \mathrm{d}^{-1}$ (R. Wilcock pers. comm.), we estimate that Atrina beds contribute up to $80 \%$ of the daily DIN supply to the harbour (Table 8). A similar calculation without Atrina (using bare sediment BNF rates) suggests an estimated $75 \%$ reduction in the summer DIN supply.

We recognise that these calculations (Table 8) have potentially large error terms, and they are not intended to be used as a nutrient budget. However, they demonstrate that the Atrina beds in Mahurangi Harbour potentially play an important role in the primary production that supports the aquaculture of Pacific oysters in this harbour. Without the Atrina beds, primary production would most likely decrease dramatically. As such changes to potential primary production would adversely affect the aquaculture industry in Mahurangi Harbour, the present decline of the Atrina beds due to increasing turbidity from catchment development is of major concern.

\section{CONCLUSIONS}

The presence of Atrina beds has an effect on the BNF in Mahurangi Harbour that varies along a turbidity gradient. In the highly turbid inner harbour, Atrina enhance sedimentation through their biodeposits. These biodeposits have the potential to smother microphytobenthos, thus reducing uptake and enhancing pelagic nutrient concentrations from Atrina excretion during the day. However, at night, the biodeposits potentially enhance nutrient loss through enhanced denitrification. With the decline in Atrina populations in the inner harbour, daytime nutrient nitrogen supplies are likely to decrease markedly but may increase slightly at night.

In the outer harbour, the presence of Atrina beds produces a small overall increase in the nutrient nitrogen supply during the day, but a substantial increase in BNF at night. In contrast with the inner harbour sites, where the nutrient increase is directly from the Atrina excretion, nutrient increases are a function of microbial activity in the sediments associated with enhanced bioturbation in the outer harbour. With Atrina beds, there is a marked increase (almost double) in BNF from the beds at night relative to adjacent bare sediments and, consequently, highest nutrient availability is likely to occur early in the morning before sunrise. Without Atrina beds, the present strong diurnal cycle of nutrient supply would weaken and overall primary production in the outer harbour would most likely reduce substantially.

In terms of nutrient supply in Mahurangi Harbour in summer, we estimate that Atrina beds potentially account for up to $80 \%$ of the nutrients available for primary production, and without them, the daily nutrient availability could decrease by as much as $75 \%$.

Acknowledgements. We thank A.-M. Schwarz and R. Budd for assistance with field work, K. Safi for phytoplankton species identification and enumeration, the Salty Dog Motel and Snell's Beach for the use of their units as a shore base station, and Drs. D. Lohrer and S. Thrush for critical review of this manuscript. This work was funded by the Foundation for Research, Science, and Technology, contract C01X0028.

\section{LITERATURE CITED}

Anderson IC, McGlathery KJ, Tyler AC (2003) Microbial mediation of 'reactive' nitrogen transformations in a temperate lagoon. Mar Ecol Prog Ser 246:73-84

Barillé L, Prou J, Héral M, Razet D (1997) Effects of high natural seston concentrations on the feeding, selection, and absorption of the oyster Crassostrea gigas (Thunberg). J Exp Mar Biol Ecol 212:149-172

Berelson WM, Heggie D, Longmore A, Kilgore T, Nicholson G, Skyring G (1998) Benthic nutrient cycling in Port Phillip Bay, Australia. Estuar Coast Shelf Sci 46:917-934

Boynton WR, Kemp WM, Keefe CW (1982) A comparative analysis of nutrients and other factors influencing estuarine phytoplankton production. In: Kennedy VS (ed) Estuarine comparisons. Academic Press, New York, p 69-90

Cahoon LB, Safi KA (2002) Distribution and biomass of benthic microalgae in Manukau Harbour, New Zealand. NZ J Mar Freshw Res 36:257-266

Cummings VJ, Thrush SF, Hewitt JE, Turner SJ (1998) The influence of the pinnid bivalve Atrina zelandica (Gray) on benthic macroinvertebrate communities in soft-sediment habitats. J Exp Mar Biol Ecol 228:227-240

Cummings VJ, Thrush SF, Hewitt JE, Funnell GA (2001) Variable effect of a large suspension-feeding bivalve on infauna: experimenting in a complex ecosystem. Mar Ecol Prog Ser 209:159-175

Dame R, Libes S (1993) Oyster reefs and nutrient retention in tidal creeks. J Exp Mar Biol Ecol 171:251-258

de Deckere EMGT, Tolhurst TJ, de Brouwer JFC (2001) Destabilization of cohesive intertidal sediments by infauna. Estuar Coast Shelf Sci 53:665-669

Delgado M, de Jonge VN, Peletier H (1991) Experiments on resuspension of natural microphytobenthos populations. Mar Biol 108:321-328

Ellis JI, Norkko AM, Thrush SF (2000) Broad scale disturbance of intertidal and shallow sublittoral soft-sediment habitats; effects on the benthic macrofauna. J Aquat Ecosyst Health 7:57-74

Ellis J, Hewitt J, Thrush S, Cummings V, Norkko A (2002) Determining effects of suspended sediment on condition of a suspension feeding bivalve (Atrina zelandica): results of a survey, a laboratory experiment and a field transplant experiment. J Exp Mar Biol Ecol 267(2):147-174

Gallegos CL, Jordan TE, Correll DL (1992) Event-scale response of phytoplankton to watershed inputs in a subestuary: timing, location, and magnitude of blooms. 
Limnol Oceanogr 7:813-828

Gibbs MM, Vant WN (1997) Seasonal changes in factors controlling phytoplankton in Beatrix Bay, New Zealand. NZ J Mar Freshw Res 31:237-248

Gibbs M, Ross A, Downes M (2002) Nutrient cycling and fluxes in Beatrix Bay, Pelorus Sound, New Zealand. NZ J Mar Freshw Res 36:675-697

Gilbert F, Souchu P, Bianchi M, Bonin P (1997) Influence of shellfish farming activities on nitrification, nitrate reduction to ammonium and denitrification at the water-sediment interface of the Thau lagoon, France. Mar Ecol Prog Ser 151:143-153

Gilbert F, Stora G, Bonin P (1998) Influence of bioturbation on denitrification activity in Mediterranean coastal sediments: an in situ experimental approach. Mar Ecol Prog Ser 163:99-107

Grasshoff K, Ehrhardt M, Kremling F (1983) Methods of seawater analysis, 2nd edn. Verlag Chemie, Weinheim

Green MO, Hewitt JE, Thrush SF (1998) Seabed drag coefficient over natural beds of horse mussels (Atrina zelandica). J Mar Res 56:613-637

Hawkins AJS, James MR, Hickman RW, Hatton S, Weatherhead M (1999) Modelling of suspension-feeding and growth in the green-lipped mussel Perna canaliculus exposed to natural and experimental variations of seston availability in the Marlborough Sounds, New Zealand. Mar Ecol Prog Ser 191:217-232

Herman PMJ, Middelburg JJ, Widdows J, Lucas CH, Heip CHR (2000) Stable isotopes as trophic tracers: combining field sampling and manipulative labelling of food resources for macrofauna. Mar Ecol Prog Ser 204:79-92

Hewitt JE, Thrush SF, Legendre P, Cummings VJ, Norkko A (2002) Integrating heterogeneity across spatial scales: interactions between Atrina zelandica and benthic macrofauna. Mar Ecol Prog Ser 239:115-128

Kemp WM, Boynton WR (1992) Benthic-pelagic interactions: nutrient and oxygen dynamics. In: Smith DE, Leffler $M$, Mackiernan G (eds) Oxygen dynamics in Chesapeake Bay: a synthesis of recent research. Maryland Sea Grant, College Park, MD, p 149-222

MacIntyre HL, Geider RJ, Miller DC (1996) Microphytobenthos: the ecological role of the 'Secret Garden' of unvegetated, shallow-water marine habitats. I. Distribution, abundance and primary production. Estuaries 19: 186-201

Malone TC, Crocker LH, Pike SE, Wendler BW (1988) Influences of river flow in the dynamics of phytoplankton production in a partially stratified estuary. Mar Ecol Prog Ser 48:235-249

Miller DC, Geider RJ, MacIntyre HL (1996) Microphytobenthos: the ecological role of the 'Secret Garden' of unvegetated, shallow-water marine habitats. II. Role in sediment stability and shallow-water food webs. Estuaries 19: 202-212

Munksby N, Benthien M, Glud RN (2002) Flow-induced flushing of relic tube structures in central Skagerrak (Norway). Mar Biol 141:939-945

Newell RIE, Cornwell JC, Owens MS (2002) Influence of simulated bivalve biodeposition and microphytobenthos on sediment nitrogen dynamics: a laboratory study. Limnol

Editorial responsibility: Otto Kinne (Editor-in-Chief), Oldendorf/Luhe, Germany
Oceanogr 47:1367-1379

Norkko A, Hewitt JE, Thrush SF, Funnell GA (2001) Benthic-pelagic coupling and suspension-feeding bivalves: linking site-specific sediment flux and biodeposition to benthic community structure. Limnol Oceanogr 46: 2067-2072

Powell AWB (1979) New Zealand mollusca: marine, land and freshwater shells. William Collins Publishers, Auckland

Quijón P, Jaramillo E, Pino M (1996) Macrofaunal assemblages associated with mussel and clam beds in an estuary of Southern Chile. Estuaries 19:62-74

Reise K (2002) Sediment mediated species interactions in coastal waters. J Sea Res 48:127-141

Riera P, Richard P (1996) Isotopic determination of food sources of Crassostrea gigas along a trophic gradient in the estuarine Bay of Marennes-Oléron. Estuar Coast Shelf Sci 42:347-360

Sartory DP (1982) Spectrophotometric analysis of chlorophyll $a$ in freshwater plankton. Technical Report TR115. Department of Internal Affairs, Hydrological Research Institute, Pretoria

Schramm W, Gualberto E, Orosco C (1984) Release of dissolved organic matter from marine tropical reef plants: temperature and desiccation effects. Bot Mar 27:71-77

Stal L (1994) Microbial matts: ecophysiological interactions related to biogenic sediment stabilization. In: Krumbein WE, Paterson DM, Stal L (eds) Biostabilization of sediments. Springer Verlag, Oldenburg, p 41-53

Strickland JDH, Parsons TR (1972) A practical handbook of seawater analysis. Bulletin 167, 2nd edn. Fisheries Research Board of Canada, Ottawa

Sundbäck K, Miles A (2000) Balance between denitrification and microalgal incorporation of nitrogen in microtidal sediments, NE Kattegat. Aquat Microb Ecol 22:291-300

Sundbäck K, Miles A, Göransson E (2000) Nitrogen fluxes, denitrification and the role of microphytobenthos in microtidal shallow-water sediments: an annual study. Mar Ecol Prog Ser 200:59-76

Sundbäck K, Miles A, Hulth S, Pihi L, Engström P, Selander E, Svenson A (2003) Importance of benthic nutrient regeneration during initiation of macroalgal blooms in shallow bays. Mar Ecol Prog Ser 246:115-126

Sundbäck K, Linares F, Larson F, Wulff A, Engelsen A (2004) Benthic nitrogen fluxes along a depth gradient in a microtidal fjord: the role of denitrification and microphytobenthos. Limnol Oceanogr 49:1095-1107

Utermöhl H (1958) Zur Vervollkommnung der quantitativen Phytoplankton-Methodik. Mitt Int Ver Theor Angew Limnol 9:1-38

Webster IT, Ford PW, Hodgson B (2002) Microphytobenthos contribution to nutrient-phytoplankton dynamics in a shallow coastal lagoon. Estuaries 25:540-551

Welsh DT, Bartoli MB, Nizzoli D, Castaldelli G, Riou SA, Viaroli P (2000) Denitrification, nitrogen fixation, community primary productivity and inorganic- $\mathrm{N}$ and oxygen fluxes in an intertidal Zostra noltii meadow. Mar Ecol Prog Ser 208:65-77

Zeldis JR (2004) New and remineralised nutrient supply and ecosystem metabolism on the northeastern New Zealand continental shelf. Cont Shelf Res 24:563-581

Submitted: June 18, 2003; Accepted: October 7, 2004

Proofs received from author(s): February 16, 2005 